\title{
Motivation And Teaching Experience: Does Teaching Experience Affect Lecturers' Motivation In Teaching Online?
}

\author{
Siti Nurul Mahfuzah Mohamada*, Mohd Azran Mohd Salleh ${ }^{b}$, Sazilah Salama, Norasiken Bakara \\ ${ }^{a}$ Faculty of Information and Communication Technology, Universiti Teknikal Malaysia Melaka, Hang Tuah Jaya, 76100 Durian Tunggal, Melaka, Malaysia \\ ${ }^{b}$ Kolej Komuniti Masjid Tanah, Paya Rumput, 78300 Melaka, Malaysia \\ *Corresponding author: mahfuzah@utem.edu.my
}

\begin{abstract}
There are a few challenges for all lecturers to apply online teaching practices. Among the problems are preparing teaching materials for online learning and lack of motivation in teaching and learning using online tools. This study intends to determine whether teaching experience affect lecturers' motivation in teaching online. The respondents consist of 149 lecturers from Jabatan Matematik dan Sains Komputer (JMSK) with different subject matter expertise. Teaching experience was assessed using a multiple choice question in demographics and the lecturer's motivation was measured using four primary dimensions i.e., ease of use (EOU), usefulness (USE), enjoyment (E), and self-confidence (SC). In order to measure these four dimensions, measurement items were adapted from previous researchers. The Wilk's Lambda within the Multivariate Tests shows the significance (p-value) is more than 0.05 , which means that the lecturer's motivation is not significantly affected by their prior experience. Study also found that most of the lecturers in the polytechnics have between 4-6 years of teaching experience with the highest percentage of 34.2\% and only one new lecturer with experience lower than one year was involved in this survey $(0.7 \%)$. To conclude, these findings indicated that teaching experience does not affect a lecturer's motivation in using online tools. Equally important, the application of appropriate teaching and learning tools makes the teaching and learning more effective in the classroom. Aided teaching techniques with several Web 2.0 applications also helped lecturers to diversify their teaching styles. It is hoped that the benefits from this study would be able to help the lecturers to be aware of the potential of their creativity and to be able to practice this in their teaching, as well as in recognizing the importance of the factors that motivate the creativity of lecturers in teaching online. This study formerly looked at the factors that motivated the lecturers in using online tools and highlighted three main factors that can affect a lecturer's motivation which are (i) knowledge; (ii) perceptions, and (iii) skills.
\end{abstract}

Keywords: Intrinsic and extrinsic motivation, e-learning, polytechnic, teaching and learning, education.

\begin{abstract}
Abstrak
Terdapat beberapa cabaran untuk semua pensyarah melaksanakan amalan pengajaran secara atas talian. Antara masalah yang dikenalpasti adalah persediaan bahan pengajaran dan pembelajaran serta kurangnya motivasi menggunakan alatan pengajaran secara atas talian. Kajian ini dijalankan untuk mengenalpasti sama ada pengalaman mengajar mempengaruhi motivasi pensyarah dalam menggunakan pengajaran secara atas talian. Responden terdiri daripada 149 pensyarah dari Jabatan Matematik dan Sains Komputer (JMSK) yang berbeza kepakaran. Pengalaman mengajar dinilai menggunakan soal selidik dan motivasi pensyarah diukur menggunakan empat dimensi utama iaitu, kemudahan penggunaan (EOU), kegunaan (USE), keseronokan (E) dan keyakinan diri (SC). Untuk mengukur empat dimensi, item ukuran telah disesuaikan daripada penyelidik sebelumnya. Pengujian The Wilk's Lambda dalam tempoh Ujian Multivariate menunjukkan nilai-p adalah lebih daripada 0.05 yang bermaksud bahawa motivasi pensyarah menggunakan bahan pengajaran atas talian tidak dipengaruhi oleh pengalaman mengajar. Kajian juga mendapati bahawa sebahagian pensyarah di politeknik mempunyai 4-6 tahun pengalaman mengajar dengan peratusan tertinggi (34.2\%) dan hanya seorang pensyarah baru dengan pengalaman kurang daripada satu tahun terlibat dalam kajian ini (0.7\%). Kesimpulannya, kajian ini menunjukkan bahawa pengalaman mengajar tidak mempengaruhi motivasi pensyarah dalam menggunakan alat pengajaran secara atas talian. Tidak kurang pentingnya, penggunaan alat pengajaran dan pembelajaran yang sesuai menjadikan pengajaran dan pembelajaran lebih berkesan dalam bilik darjah. Teknik pengajaran yang dibantu dengan beberapa aplikasi web 2.0 juga membantu pensyarah untuk mempelbagaikan gaya pengajaran mereka. Adalah diharapkan bahawa manfaat daripada kajian ini akan dapat membantu pensyarah untuk menyedari potensi kreativiti mereka dan dapat mengamalkannya dalam pengajaran mereka, dan juga dalam mengenalpasti kepentingan faktor yang mendorong kreativiti pensyarah dalam pengajaran atas talian. Kajian ini juga telah melihat faktor-faktor yang mendorong pensyarah dalam menggunakan alat dalam talian dan menekankan tiga faktor utama yang boleh mempengaruhi motivasi pensyarah iaitu (i) pengetahuan; (ii) persepsi dan (iii) kemahiran.
\end{abstract}

Kata kunci: Intrinsik, ekstrinsik, motivasi, e-pembelajaran, politeknik, pengajaran dan pembelajaran, pendidikan

(C) 2017 Penerbit UTM Press. All rights reserved

\subsection{INTRODUCTION}

Nowadays, the use of e-learning in teaching and learning especially in polytechnic cannot be avoided when designing instructional activities. The exposure to an appropriate technology should combine all materials, strategies, and adopted methodology. Educators need to provide effective teaching and quality classroom activities for their students. This will definitely affect the style of learning and students' perception to the tools used by educators. This study involved lecturers of polytechnics in Malaysia. In general, polytechnics are public- 
funded higher educational institutions that offer technical and vocational courses of study to upper-secondary school leavers, leading to the award of diplomas and certificate qualifications. There are few challenges for all lecturers when applying online teaching practices. There are two main problems that have been identified in this study. Among the problems are (i) preparing teaching materials in online learning; and (ii) lack of motivation in teaching and learning using online tools.

The first problem identified was the preparation of teaching materials in online learning. Providing various types of teaching materials is one of the important elements to ensure that teaching activities in the classroom are more enjoyable and retain students' attention in class. In order to give benefits to all students, the appropriate teaching methods must be prepared to meet all students' needs. Although the traditional teaching method has been practiced in the classroom, there are still weaknesses that should be considered to produce excellent students. If lecturers are able to understand the trend of a student's learning style, they can deliver a more focused teaching when compared with the existing teaching style. The importance of active participation of educators in the design of learning scenarios is considered crucial (Griffiths \& Blat, 2005). Nevertheless, the biggest impact is the need to differentiate between the teaching aids that can provide a variety of experiences and rich activities. Moreover, lecturers are faced with the younger generation or better known as 'Generation-Y' that is not only highly skilled in ICT but also constantly exposed to a source of information and variety of media as well as the opportunity to communicate with various parties within and outside the country (Alias, Zainal, \& See, 2012).

The second problem is related to a lack of motivation among lecturers in teaching and learning using online tools at Malaysian institutions. Previous studies (Embi, 2011; Jamia'an, 2010; Isa, Rashidah, Nor, \& Rohayu, 2001; Yusof \& Mariani, 2001) stated that there are a lot of problems and challenges related to online teaching and learning arising in institutions. Embi (2011) reported that a total of 1,635 Malaysian HEIs lecturers revealed that the main reasons why they were not using e-learning in the classroom are because they lack training and time; prefer traditional teaching methods; lack technical support; lack facilities; it is an additional burden to the existing teaching load; and other reasons. Time constraint at their workplaces also adds to the environment constraint as mentioned in Jamia'an, (2010). A study was conducted at Politeknik Mukah Sarawak where the author states that the learning environment is not conducive in allowing the preparation of learning materials. This opinion is supported by Isa et al. (2001), where the modification process and design course contents are adapted to carry out an effective teaching method. This consumes a lot of time, effort, and commitment from lecturers. A recent research in education also indicates that there is a lack of creative and innovative teaching strategies among the educators (Yusof \& Mariani, 2001).

Therefore, all lecturers should equip themselves with more ICT skills than students. They must also use all existing platforms and mediums not only as a channel of communication with the students but also to assist in the process of teaching and learning. Lecturers should always be prepared to make changes in the teaching and learning environment. Innovation should be taken in order to promote effective teaching and learning in the classroom. Not only that, educators needs the knowledge, expertise, and a variety of tools to design and create interactive teaching materials. However, not all educators are familiar with e-learning tools especially web 2.0 application. Nevertheless, a few studies have been conducted involving learning tools rather than teaching tools. Teaching methods should be considered in order to produce effective teaching tools.

Teaching through e-learning is not something new in the world of education especially in higher education. It allows students to access information anytime and anywhere, as well as easily for lecturers to prepare teaching materials before starting a class. E-learning can also motivate lecturers in teaching through a variety of activities and modern teaching aids that cater to specific topics. The use of computers in the teaching and learning process as well as the application involving the Internet directly helps in the management of the learning process especially in the polytechnics (Rassiah et al., 2011). Mohamad et al. (2014) highlighted that 87\% of polytechnic students agreed that online learning materials (e-content) should be created in their courses and $100 \%$ of the students agreed that online learning materials (e-content) should be developed for future learning.

Study from Zakaria et al. (2010) reported that almost all students have high access to computers and other ICT devices. Most of Malaysian undergraduates own portable devices which means that students can access the Internet facilities and use a wide range of technology tools for communication. Students are actually exposed to the Web 2.0 technologies (Salam et al., 2014) and lecturers can use rapid e-learning tools to provide teaching materials online. The rapid e-learning tools have the potential of its own as they require a low production cost, reduced development time, increase speed of response to emerging needs, provide more control to subject matter experts, and provide easier maintenance and updates. It can provide very fast transfer, is fast to develop and has real impact on performance. Some of these tools aid each slide as a learning object and allow adding tests as well as online activities between the slides. Some of these softwares are online services, and the others are desktop applications installed into personal computers.

The rapid e-learning allows users to develop courseware which can be developed in less than three weeks. The subject matter experts (SME) will act as a primary resource for development, easier to use as a well-known tool (e.g. PowerPoint), and provide userfriendly templates form the starting point for coursewares. A simple assessment, feedback, and tracking are usually provided in the rapid elearning tool. Media elements which enhance learning but do not create technology barriers may be included (e.g. voice), and learning modules can be taken in one hour or less, often in less than 30 minutes. Synchronous (scheduled or live) and asynchronous (self-paced) models may be utilized in this tool. The rapid e-learning typically compresses the instructional design and development phases by eliminating steps and leveraging new tools. It allows instructional designers and subject matter experts to take advantage of authoring tools that change existing content into information and instruction quickly. In general, the rapid e-learning content can be built in days or weeks; not all contents can be developed in the rapid e-learning method. It is best used for instruction that focuses on lower learning levels such as knowledge and comprehension in which the content is available and usable. It is suitable for frequently updated and time-sensitive content.

Rapid e-learning can overcome two major challenges in traditional e-learning, which is long development cycle and knowledge gap among the e-learning development team members. This is because of the compressed or eliminated steps and subject matter experts who act as the primary source for development of the instructional content. It requires minimum technical knowledge of skills or third party support. Haghshenas, Maryam, and Hoda (2012) also list the best rapid tools for the development of content for e-learning. Table 1 shows the comparison between rapid e-Learning and traditional e-learning. 
Table 1 Comparison between rapid e-learning and traditional e-learning

\begin{tabular}{|c|c|}
\hline Rapid E-Learning & Traditional E-Learning \\
\hline $\begin{array}{l}\text { SME can use the tool - as simple to use as Microsoft } \\
\text { PowerPoint or Word - one to two days learning curve }\end{array}$ & $\begin{array}{l}\text { Power User tool - graphic specialists, technically sophisticated users - } \\
\text { two weeks to six months learning curve }\end{array}$ \\
\hline Produces content that is easily deployed & May include complex interactions, high band width content, plug-ins \\
\hline Does not require a team of people to create a course & $\begin{array}{l}\text { Need a team that has advanced skills; e.g. programming, graphic } \\
\text { design, instructional design }\end{array}$ \\
\hline $\begin{array}{l}\text { Course creator imports graphics, clip art, simulations, and } \\
\text { animations }\end{array}$ & Course creator creates graphics, simulations, and animations \\
\hline $\begin{array}{l}\text { Company understand the value of e-learning (understands the } \\
\text { cost, time, and accessibility savings of moving classroom } \\
\text { training to the web) }\end{array}$ & Company has not necessary embraced e-learning \\
\hline Works well in a bottom up initiative structure & $\begin{array}{l}\text { Works well in a top down initiative structure (larger budgets, larger } \\
\text { projects) }\end{array}$ \\
\hline $\begin{array}{l}\text { Visual design (look and feel) is supplied by company - course } \\
\text { developer is not involved }\end{array}$ & Visual design (look and feel) is integral part of development process \\
\hline
\end{tabular}

\subsection{RELATED WORK}

The beginning of the latest technology greatly changed the pattern and direction of technical education especially in the polytechnic department. With this technology, it actually provides an opportunity for students to further their knowledge in accordance with the objectives of the polytechnic in Malaysia. Hennessy et al. (2006) stated that computer technology can help students form new knowledge and applications. There are many potential uses and benefits for the educational use for reading and writing from the web to enhance learning. Social software can enhance the existing teaching and learning approaches as well as extend their reach and effectiveness.

In order to increase motivation, the teaching material should be prepared with different styles of learning and suitable for the students. The lecture presentations must be usable to the largest number of students possible; that includes a variety of communication modalities, content representations, engagement methods, and evaluation techniques (Thomson et al, 2015). Lecturers should keep in mind that students can use any devices to access learning materials (e.g., desktop or mobile). Lecturers can also use various elements of elearning to prepare interactive teaching activities' and strategies. E-learning has enable students or lecturers to access online learning or teaching resources. There are a lot of platforms for lecturers to prepare teaching materials. Hsu et al. (2014) agreed that Web 2.0 applications empower users with a venue for personal expression, sharing, communicating, and collaborating with others. The authors also mentioned that learning through collaboration with Web 2.0 applications gives the opportunities to users and should be applied in education. The resources and interactions in a classroom depend on the curriculum that the class is working on. The Internet is not an approach to education, but rather a tool that can be used with almost any learning theory.

Elkaseh et al. (2015) analysed and investigated factors that impact teachers and students who are using e-learning in higher education. The authors stated that social influence significantly affects the students' 'Perceived Usefulness and Perceived Ease of Use of E-Learning' but there were no effects on the teachers' 'Perceived Usefulness and Perceived Ease of Use of E-Learning' in Libyan higher education. According to Arkorful and Nelly (2015), there are seven advantages of adoption of e-learning in education: (i) flexibility of time and place; (ii) ease of access to a huge amount of information; (iii) motivates students to interact with each other; (iv) cost effective that there is no need for the learners to travel; (v) provide different learning methods; (vi) lecturer act as a facilitator, and (vii) the use of elearning allows self-pacing. Overall, e-learning involves the use of a variety of digital tools for teaching and learning that enables learners' to study anytime and anywhere. Figure 1 shows the Web 2.0 activities that were applied by Mohamad et al. (2014).
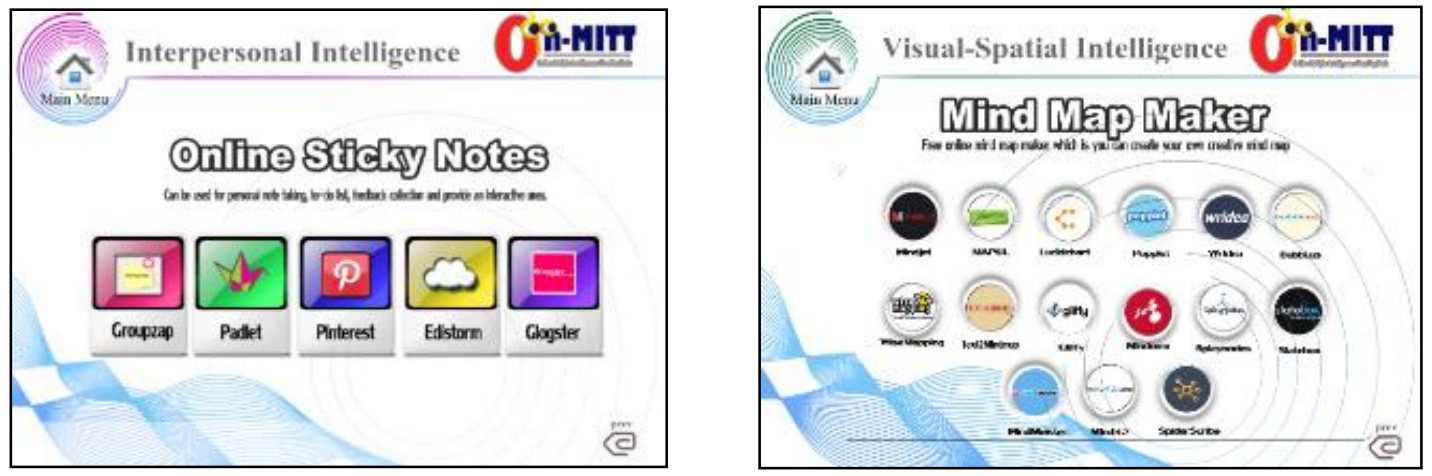

Figure 1 Web 2.0 activities 
Motivation is the drive to the will and desire to succeed or achieve something. According to Woolfolk (1990), motivation refers to an internal power rise, directing, as well as controlling interest and human behaviour. The motivation in this treatment refers to when the lecturers feel the motivation when using the On-MITT (Mohamad et al., 2014) in the classroom (Figure 2). The motivation used in this study is divided into two: (i) intrinsic motivation covers the ease of use and enjoyment, (ii) extrinsic motivation covers the usefulness and self-confidence.

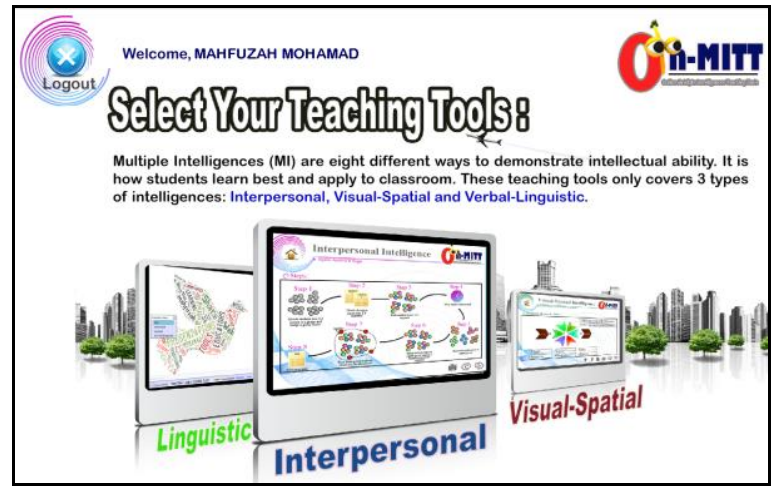

Figure 2 Online multiple intelligence teaching tools

The motivation variables have been identified in this study and illustrated in Figure 3 (Mohamad et al., 2015). The variables are an adaptation from the ARCS model that was proposed by Keller (2008). The model consists of four main areas: Attention, Satisfaction, Relevance, and Confidence. The authors also mentioned that intrinsic motivation correlated with interest, enjoyment, felt competence, and positive coping. Keller suggested that encouragement and support intrinsic enjoyment of the learning experience can promote Satisfaction. Keller also presents usefulness as one of the Relevance strategies and ease of use as of the Attention strategies. In the Huett et al. (2008) study, the results showed that confidence levels of online learners increased after exposure to the Confidence strategies.

Recently, Keller (2016) upgraded the motivation model from ARCS to ARCV-S (an acronym for attention, relevance, confidence, satisfaction, and volition). The new variable was called volition, which was similar to self-regulation (Zimmerman, 2001). It incorporated variables and strategies related to persistence. Volitional refers to the degree of commitment towards achieving the learning requirements and whether they will persist to the end. Keller also suggested three strategies to develop motivating learning experiences as the following: (i) Create a felt gap; (ii) Flip the classroom; and (iii) Produce a problem-based learning environment. These three strategies can use specific techniques or more comprehensive teaching strategies and models to be incorporated into a course.

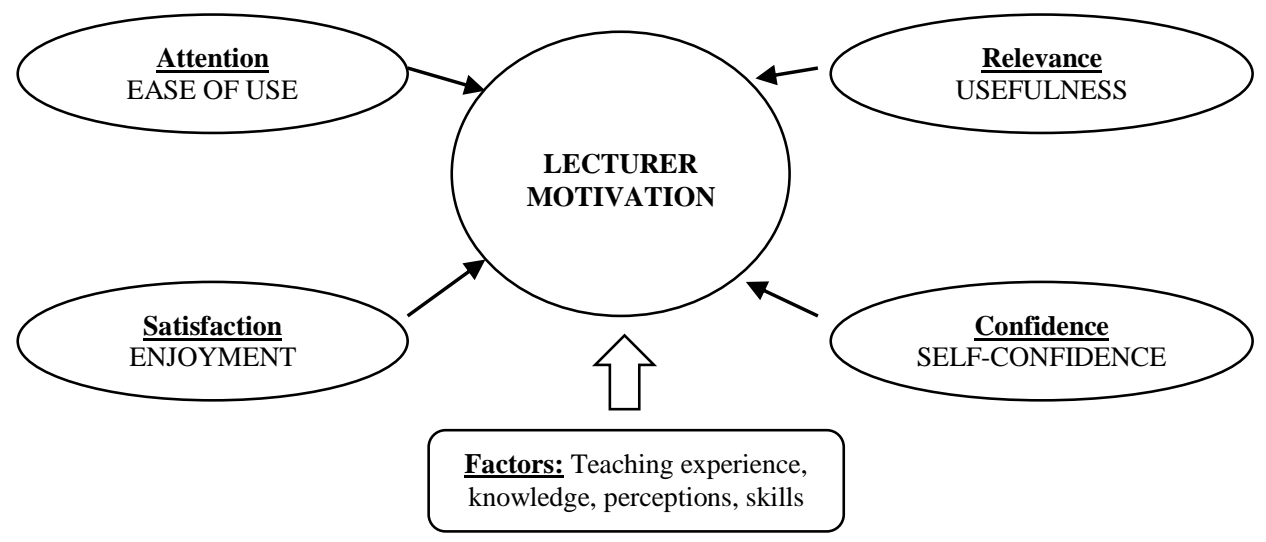

Figure 3 Motivation variables 


\subsection{MATERIALS AND METHODS}

Teaching experience was assessed using a multiple choice question in demographics and the lecturer's motivation is measured using four primary dimensions i.e., ease of use (EOU), usefulness (USE), enjoyment (E), and self-confidence (SC). In order to measure these four dimensions, measurement items were adapted from previous researches. Data was collected using these measurement scales. Before this data is used to test the hypotheses, data screening will be conducted. This will include missing value exclusion and normality test. It will be followed by reliability analysis and multicollinearity tests to satisfy the assumptions of multivariate analysis. In the end, MANOVA analysis was conducted to test the hypotheses.

The motivation survey questionnaire adapted to measure the lecturer's motivation to use online learning is shown in Figure 4. The questionnaire consists of 22 items covering four factors of motivation: Ease of Use (6 items), Enjoyment (4 items), Usefulness (6 items), and Self-Confidence (6 items). Each item consists of a five point Likert Scale where the options were coded 1 for 'Strongly Disagree', 2 for 'Disagree', 3 for 'No opinion', 4 for 'Agree', and 5 for 'Strongly Agree'. Population for the lecturers at Jabatan Matematik dan Sains Komputer (JMSK), Polytechnic was 412 and the sample size selected in this study was 149.

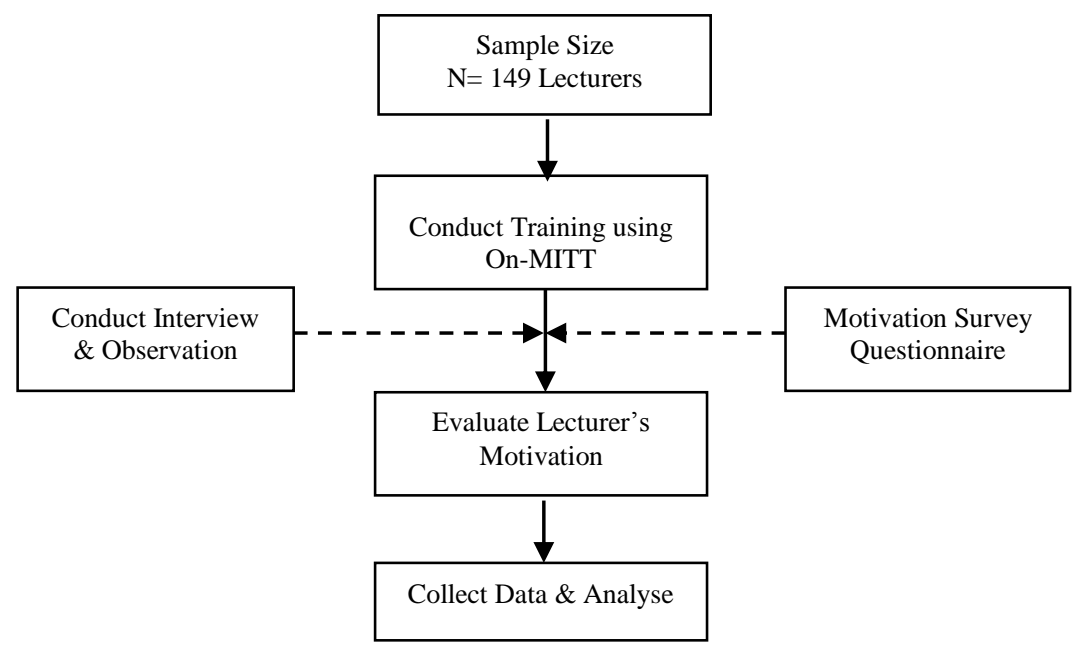

Figure 4 Lecturers' motivation flow

For all experimental situations, lecturers were given a one-day training using a tool called On-MITT. From the training, lecturers learned how to design and apply it in the classroom. Lecturers were also exposed to Web 2.0 applications that benefit the lecturers and students. After completing the training and providing interactive teaching activities to their students, lecturers were asked to fill the motivation survey form using online survey.

The letter of application to conduct e-learning training and evaluation to lecturers were distributed to ten polytechnics. However, only four polytechnics allowed for the study to be conducted. In the training and evaluation, a total of 160 questionnaires were distributed and out of that, 149 responses were found usable. The respondents consist of 19 males and 130 females from JMSK lecturers with different SME. From the survey, polytechnics involved in the evaluation of e-learning training that took around four months are Politeknik Melaka (PMK), Politeknik Shah Alam (PSA), Politeknik Merlimau Melaka (PMM), and Politeknik Seberang Perai (PSP). Figure 5 shows the percentage of respondents by polytechnics.

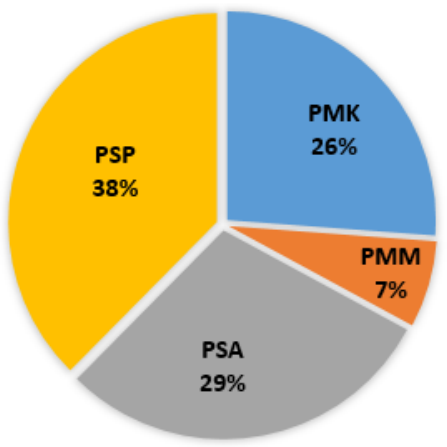

Figure 5 Percentage of respondent by polytechnics 
In this study, the testing methodology was built to access the output. This testing model is shown in Figure 6.

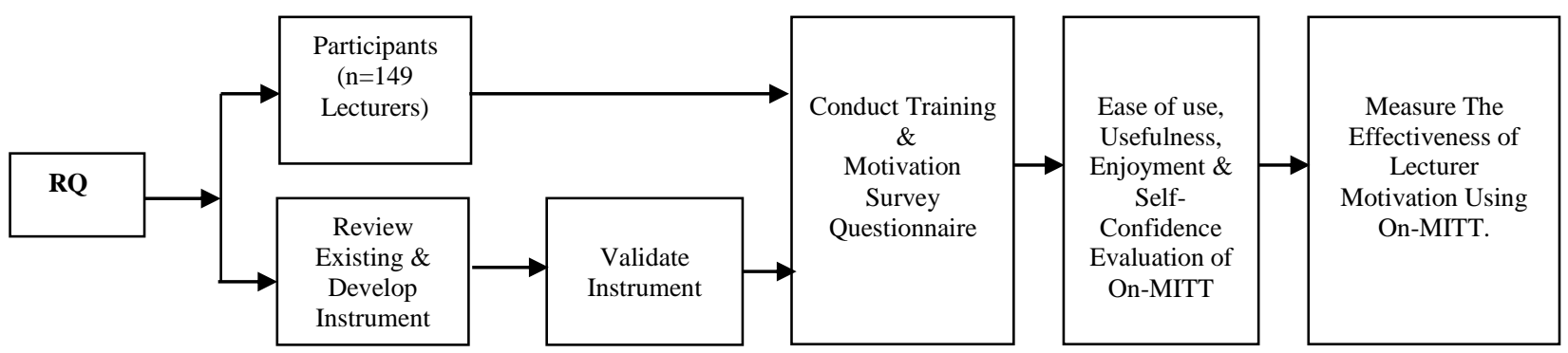

Figure 6 Testing Model

E-learning training and evaluation involved four polytechnics in Malaysia that had computer equipment and internet access. There are two types of motivations discussed in this study: (i) Intrinsic Motivation, and (ii) Extrinsic Motivation. Intrinsic motivation has been studied vastly, and in the opinion of Deci and Ryan (2000), intrinsic motivation is very important to lecturers. In fact, the analysis concluded that intrinsic factors enhanced the creativity among lecturers in the polytechnics. This matches with the opinion of Brophy (1983) who states that the results of intrinsic motivation are based on the character of the individual personality. Furthermore, intrinsic motivation to achieve a goal is closely related to the activities for one's own benefit and the desire of external activity.

On the other hand, external motivation or extrinsic motivation is the willingness to perform a task because there are external rewards or because he or she does not want to be punished (Mohd \& Abdullah, 2002). In this case, the factors that cause a person to feel good are not on the job. Extrinsic motivation is the total opposite of intrinsic motivation, which refers to doing something just for fun. It is also related to external driving factors, such as attention, incentives earned, praise, and encouragement from other parties. According to Amabile (1996), intrinsic motivation is conducive to creativity, whereas extrinsic motivation is detrimental. According to Maslow's theory in the early stages, external motivation drives a person to achieve the desirable requirements. It is the individual's internal that has been cultivated by external qualities in the task set.

\subsection{RESULTS AND DISCUSSION}

From the demographic information, education background of the respondents is divided into IT lecturers (47.7\%) and non-IT lecturers (52.3\%). JMSK acts as a support department to other technical departments such as JTMK, JKE, JPA, JKM, and others. Non-IT lecturers are involving various education background; such as electrical engineering, general studies, and commerce lecturers; under the same department. Table 2 presents the demographic characteristics of the respondents. Based on the demographic information gained from this survey, it was found that most lecturers' aged between 30-35 years has the highest percentage (34.9\%). There are also young lecturers with $7.4 \%(\mathrm{~N}=11)$. This study also found that most of the lecturers in the polytechnics have teaching experience between 4-6 years; with the highest percentage of $34.2 \%$. Only one new lecturer with experience of less than one year was involved in this survey (0.7\%). A majority of the respondents have more than one year teaching experience. The findings indicated that marginally more than $50 \%$ of the lecturers are experienced in the Polytechnics. They have been working in the Polytechnics for not more than 1 year or less. However, there are more senior lecturers in this study that can give a good feedback and response for the study. Overall, there is a good mixture of both experienced as well as new lecturers in the Polytechnics system. In order to identify the research questions, the following hypothesis was derived from extensive literature. Data were analyzed using SPSS for Windows version 20.0. The instrument used in this study was the Motivation Survey Questionnaire.

Hypothesis:

There is no significant difference in the combined mean score between motivation and teaching experience.

\section{Missing Values}

Missing data can be the result of any systematic event external to the respondent (such as data entry errors or data collection problems) or action on the part of the respondent (such as refusal to answer) that leads to missing values (Enders, 2006). In order to conduct analysis, it is important to estimate these missing values. One method used for this study was to employ mean imputation. There were no missing values in the data set as shown in Table 3.

\section{Normality Test}

An important assumption of data distribution in multivariate analysis is the data normality, particularly the departure from multivariate normality or a strong kurtosis (skewness) (Hair et al., 1998). In other words, many analyses require that the dependent variable is approximately normally distributed for each category of independent variable. In order to do this, the following numeric outputs are investigated: (i) Skewness and Kurtosis- $Z$ values (should be between +1.96 and - 1.96) and (ii) The Shapiro-Wilk test p-value (should be above 0.05 ). Table 4 shows the results of skewness and Kurtosis $-\mathrm{Z}$ values. The bold values in the table show the $\mathrm{Z}$-Values. All of these 
values should be between +1.96 and -1.96 . The $\mathrm{Z}$ values in the table above are all between the specified ranges which show that the data is approximately normally distributed. Besides that, all of the p-values in the Shapiro-Wilk test are also above 0.05, indicating normality of the data.

Table 2 Demographic characteristics

\begin{tabular}{cccc}
\hline Variables & \multicolumn{2}{c}{ Demographic Characteristics } & \\
& Category & Frequency & Percent \\
\hline Gender & Female & 130 & 87.2 \\
& Male & 19 & 12.8 \\
\hline Education & IT & 71 & 47.7 \\
Background & Non-IT & 78 & 52.3 \\
\hline Polytechnic & PMK & 39 & 26.2 \\
& PMM & 10 & 6.7 \\
& PSA & 44 & 29.5 \\
& PSP & 56 & 37.6 \\
\hline Ethnicity & Malay & 141 & 94.6 \\
& Chinese & 5 & 3.4 \\
& Indian & 2 & 1.3 \\
& Others & 1 & 0.7 \\
\hline Age & $20-25$ & 11 & 7.4 \\
& $26-30$ & 40 & 26.8 \\
& $31-35$ & 52 & 34.9 \\
& $36-40$ & 33 & 22.1 \\
& Above 40 & 13 & 8.7 \\
\hline Experience & Less than 1 & 1 & 0.7 \\
& $1-3$ & 19 & 12.8 \\
& $4-6$ & 51 & 34.2 \\
& $7-9$ & 45 & 30.2 \\
& Over 9 & 33 & 22.1 \\
\hline
\end{tabular}

Table 3 Missing values analysis

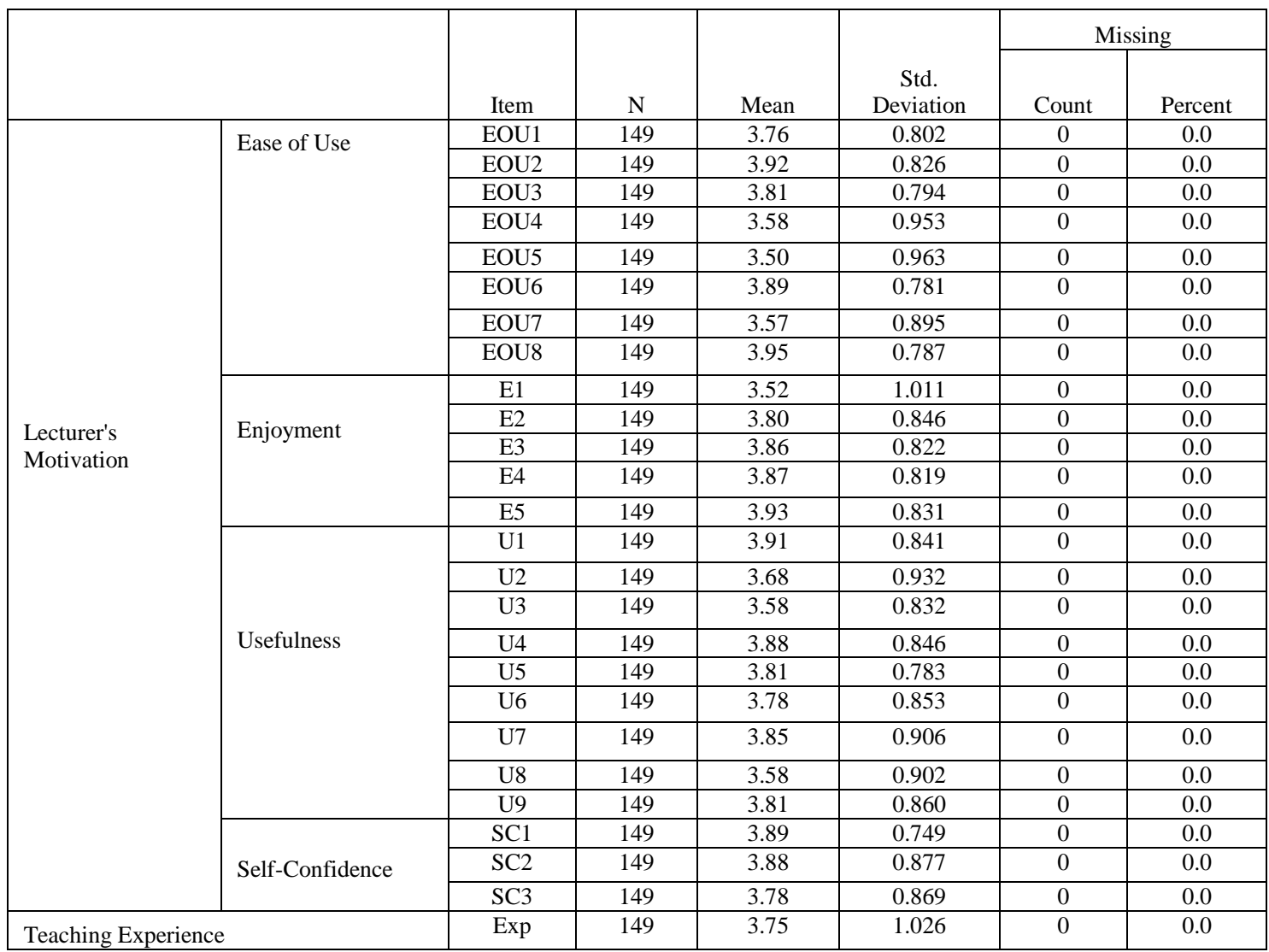


Table 4 Normality test

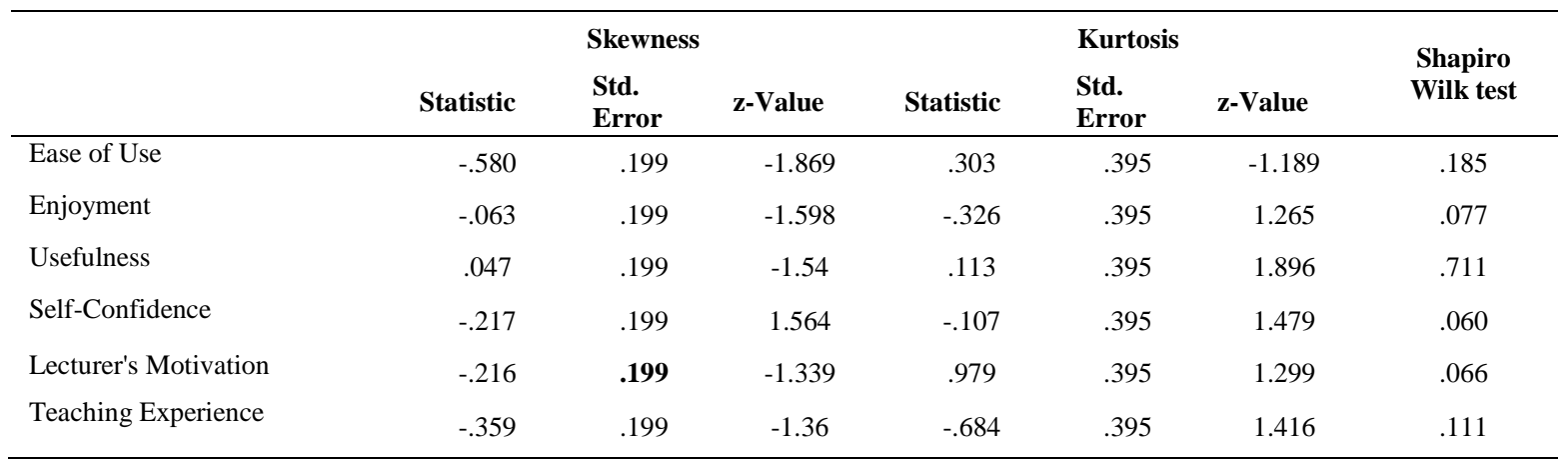

\section{Reliability and Validity Test}

Once the measurement items for the variables are determined, the researcher has to ensure that these measurements are reliable and valid. Reliability is defined as 'an indicator of a measure's internal consistency'. Validity is defined as 'the accuracy of a measure or the extent to which a score truthfully represents a concept' (Zikmund et al., 2010). The results of the reliability tests on the scales to measure a lecturer's motivation using On-MITT show that the Cronbach's Alpha values were within the range of 0.699, 0.760, 0.788, and 0.0675, respectively. The values in the range of $0.6<\alpha<0.70$ are still acceptable and the values above 0.7 are considered good (Nunnally \& Bernstein, 1994 ; Nunnally, 1978). Therefore, it can be concluded that the internal consistency of the data was achieved. As shown in the table below, the Cronbach's Alpha values for both the scales are above 0.6, which means that the scales are reliable. Table 5 presents the Cronbach's Alpha values for all the variables.

Table 5 Reliability analysis

\begin{tabular}{lccc}
\hline Construct & No. of Items & Cronbac's Alpha & Results \\
\hline Ease of Use (EOU) & 8 & 0.699 & Reliable \\
Enjoyment (E) & 5 & 0.760 & Reliable \\
Usefulness (USE) & 9 & 0.788 & Reliable \\
Self-Confidence (SC) & 3 & 0.675 & Reliable \\
Teaching Experience & 1 & Single-item does not need reliability analysis \\
\hline
\end{tabular}

Another type of validity is called construct validity, which is used to ensure that the measure actually measures what it is intended to measure. It was ensured by adopting and adapting questions from previous researches including Lobb et al. (2005). The measures based on existing studies were used to ensure high content validity. To check the validity of the data, the KMO and Bartlett's Test were used in this data. The $\mathrm{KMO}=0.792$; where it is more than 0.5, and the Bartlett's Test $(\mathrm{sig}=0.000)$ was significant because the value $<0.05$ (Table 6$)$.

Table 6 KMO and bartlett's test

\begin{tabular}{|lll|}
\hline Kaiser-Meyer-Olkin Measure of Sampling Adequacy. & .792 \\
Bartlett's Test of Sphericity & Approx. Chi-Square & 1407.877 \\
& df & 300 \\
& Sig. & .000 \\
\hline
\end{tabular}

\section{Multivariate Analysis: MANOVA Analysis}

As the name indicates, multivariate analysis comprises of a set of techniques dedicated to the analysis of data sets with more than one variable. One of these techniques is called a one-way multivariate analysis of variance (MANOVA). In order to assess the effect of a single independent variable on multiple dependent variables, MANOVA was applied. The one-way multivariate analysis of variance (one-way MANOVA) is used to determine whether there are any differences between independent groups on more than one dependent variable.

For this study, teaching experience was regarded as the independent variable whereas ease of use, usefulness, enjoyment, and selfconfidence were four dependent variables. Table 7 presents the results of the MANOVA analysis. The Wilk's Lambda within the Multivariate Tests in the table below shows the actual results of the one-way MANOVA. As shown in the table above, the significance (pvalue) is more than 0.05 , which means that lecturers' motivation is not significantly affected by their prior experience. 
Table 7 Multivariate tests

\begin{tabular}{|c|c|c|c|c|c|c|}
\hline & Effect & Value & $\mathrm{F}$ & Hypothesis df & Error df & Sig \\
\hline \multirow{4}{*}{ 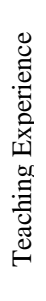 } & Pillai's Trace & 0.088 & 0.812 & 16 & 576 & 0.673 \\
\hline & $\begin{array}{l}\text { Wilks' } \\
\text { Lambda }\end{array}$ & 0.914 & 0.802 & 16 & 431.4 & 0.684 \\
\hline & $\begin{array}{l}\text { Hotelling's } \\
\text { Trace }\end{array}$ & 0.091 & 0.793 & 16 & 558 & 0.695 \\
\hline & $\begin{array}{c}\text { Roy's Largest } \\
\text { Root }\end{array}$ & 0.039 & $1.405 \mathrm{c}$ & 4 & 144 & 0.235 \\
\hline
\end{tabular}

Since the probability value obtained from SPSS 20.0 for Windows (Pillai's Trace $=0.673$ ) is larger than the predetermined alpha value (0.05), the null hypothesis was accepted. To conclude, teaching experience does not affect lecturers' motivation in using online tools. Therefore, this study already looked at the factors that motivated the lecturers in using online tools. Mohamad et al. (2015) highlighted three main factors that can affect lecturers' motivation which are (i) knowledge; (ii) perceptions, and (iii) skills as shown in Figure 7. Knowledge refers to education background of the lecturers, perceptions is the intrinsic factor that influence positive or negative motivation to the lecturer while skills refers to the professional certificate that the lecturers hold and applied in teaching methods. The factors studied were only in terms of intrinsic and extrinsic motivation.

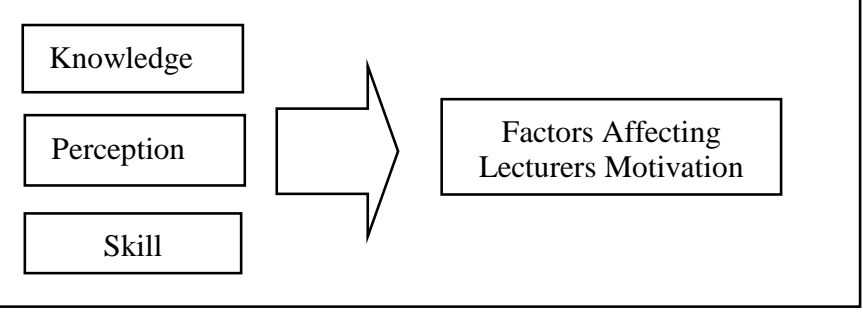

Figure 7 Factors affecting lecturers' motivation using online teaching tools

Discussion

As the internet and WWW are established, the polytechnics in Malaysia or other technical institutions will be increasingly challenged to address the educational and training needs of knowledge workers or lecturers in the digital world of education. The polytechnic lecturers will need to develop learning programmes for lifelong learning anytime and anywhere, and just-in-time work-integrated learning. The education in Malaysia will be challenged to integrate internet and related technologies into management education in ways that reflect the changes these technologies are forcing into the workplace. Web-based learning and teaching concepts among lecturers in the polytechnics offer one vision in order to meet these challenges.

All lecturers in Malaysia are therefore poised to benefit from all the fast economic and technological expansion of ICT around us. The question worth raising is whether the Malaysian polytechnic lecturers will have the flexibility, dynamism, and adaptability to adjust constantly to the challenges of the rapidly changing technology and the demand of society. All lecturers must be prepared and geared up adequately to take the advantage of the tremendous ICT prospect for a balanced knowledge construction and creation.

When developing a multimedia system, all the learning theories and models of teaching should be considered and adapted to the system. The designer should give attention to integrate all the technology to match the needs of the students. Based on the development of the On-MITT, these two theories are combined as once. The cognitive theory underscores the need for a support system to help transfer and retent knowledge on the current memory as well as long term memory. Besides that, the theory of constructivism emphasizes the ability of a system to foster and stimulate the ability of users to explore and discover knowledge.

On-MITT provides activities based on the students' centred learning approach. Educators need to act as facilitators and help students if necessary. ICT technologies are now able to help stimulate the minds of students, encourage creative activities that could potentially enrich the teaching and learning process. The integration of ICT in the teaching and learning process can produce students who are more knowledgeable, productive, intelligent, competent at problem solving, and allow students to develop soft skills (Hussain, 2007). This means that ICT can be an advantage if wisely used by educators. This opinion is supported by Idrus and Mccomas (2006) and Brushn and Saye (2008), who emphasized that technological development is a catalyst to produce an authentic learning environment.

Therefore, this study looked at the lecturers' motivation in using online tools. It is hoped that the benefits from this study would be able to help the lecturers be aware of the potential of their creativity and to be able to practice it in their teaching, as well as in recognizing the importance of the factors that motivate the creativity of lecturers in the teaching with different styles of strategies. Finally, it was found that the respondents agreed that these three factors; (i) knowledge; (ii) perceptions, and (iii) skills, affected the motivation among lecturers to use online tools, and teaching experience did not affect their motivation in using online tools. 


\subsection{CONCLUSION}

ICT awareness among polytechnic lecturers is at different levels. Hence, support and ongoing training are needed so that they have the basic skills in online learning technology. This would allow them to select the appropriate teaching aids for the teaching and learning process. There are brilliant and expert lecturers who use conventional strategies at the polytechnics. However, excellence and expertise should be integrated with the use of e-learning that is exciting, interactive, and developmentally appropriate currently. It is hoped that the benefits from this study would be able to help the lecturers be aware of the potential of their creativity and to be able to practice it in their teaching, as well as in recognizing the importance of the factors that motivate the creativity of lecturers in teaching.

\section{References}

Alias, A.K., Zainal, A. A. \& See, C. M. (2012). The Quest for Teaching Excellence. Centre for Development of Academic Excellence (CDAE). Malaysia: Universiti Sains Malaysia.

Amabile, T.M., (1996). Creativity in Context. Boulder, CO: Westview Press.

Arkorful, V., \& Nelly, A. (2015). The role of e-learning, advantages and disadvantages of its adoption in higher education. International Journal of Instructional Technology and Distance Learning. 12(1), 29-42.

Brophy, J. (1983). Conceptualizing Student Motivation. Educational Psychologist, 18, 200-215.

Brush, T., \& Saye, J., (2008). The Effects of Multimedia-Supported Problem-based Inquiry on Student Engagement, Empathy, and Assumptions About History. Interdisciplinary Journal of Problem-based Learning. 2(1)

Deci, E. L. \&Ryan, R. M. (2000). The "What" And "Why" Of Goal Pursuits: Human Needs And The Self-Determination Of Behavior. Psychological Inquiry, 11, 227268.

Elkaseh A. M., Kok W. W. \& Chun C. F. (2015). The Acceptance of E-learning as a Tool for Teaching and Learning in Libyan Higher Education. International Journal of Information Technology, 3(4), 1-11.

Embi, M. A. (2011). Web 2.0 Tools in Education: A Quick Guide. Malaysia: Univesiti Kebangsaan Malaysia.

Griffiths, D. \& Blat, J. (2005). The Role of Teachers in Editing and Authoring Units of Learning using IMS Learning Design. Advanced Technology for Learning, 2(4).

Haghshenas, M., Maryam, K. \& Hoda, K. (2012). E-Learning and Authoring Tools: At a Glance. International Journal of Research and Reviews in Applied Sciences, $10(2), 259-263$

Hair, J. F., Anderson, R. E, Tahtam, R. L and Black, W.C. (1998). Multivariate Data Analysis, (5th ed.). Upper Saddle River, NJ: Prentice Hall.

Hennessy, S., Deaney, R. \& Ruthven, K. (2006). Situated Expertise in Integrating Use of Multimedia Simulation into Secondary Science Teaching. International Journal of Science Education, 28(7), 701-732.

Hsu, Y, Yu-hui, C. \& Barbara, L. G. (2014). Web 2.0 Applications and Practices for Learning Through Collaboration. Handbook of Research on Educational Communications and Technology, 747-758.

Huett, J. B, Kevin, E. K., Leslie, M. \& Kimberly, C. H. (2008). Improving the Motivation and Retention of Online Students Through the Use of ARCS-Based E-mails. The Amer Jrnl of Distance Education, 22, 159-176.

Hussain, R. M. R., (2007). PLEaSE Strategies For Soft Skills Development. Prosiding Persidangan Pengajaran dan Pembelajaran di Peringkat Institusi Pengajian Tinggi (CTLHE07), pp. 217-225.

Idrus, R. M. and McComas, K. (2006). Technology: Facilitating the transformation of learning. International Journal of the Computer, the Internet and Management, $14,5.1-5.9$

Isa, R.M., Rashidah, A., Nor, L.A., \& Rohayu, A.G. (2001). E-Pembelajaran: Isu dan Cabaran Perlaksanaan di Malaysia. Malaysia: Universiti Kebangsaan Malaysia.

Jamia'an, M. (2010). Tinjauan Mengenai Penggunaan E-Pembelajaran (E-Learning) Dalam Kalangan Pensyarah-Pensyarah Di Politeknik Mukah Sarawak. Kolokium Penyelidikan Dan Pembangunan Pendidikan Politeknik Zon Sabah \& Sarawak, 98-108.

Keller J.M. (2008). First Principles of Motivation to learn and e3-learning. Distance Education, 29(2), 175-185.

Keller, J. M. (2016). Motivation, Learning, and Technology: Applying the ARCS-V Motivation Model. Participatory Educational Research (PER). 3(2), 1-13.

Lobb and Alexandra, (2005). Consumer trust, risk and food safety: A review. Food Economics - Acta Agriculturae Scandinavica, 2(1), 3-12.

Mohamad, S.N.M, Sazilah, S., Mohd A. M. S., Norasiken B., \& Linda K.M.S. (2014). The Effectiveness of Online Multiple Intelligences Teaching Tools (On-MITT) on Improving Lecturers' Motivation. International Journal WIT Transactions on Information and Communication Technologies for Education, 58(1), 491498.

Mohamad, S.N.M., Salam, S., Bakar, N. \& Sui, L.K.M. (2014). Online Multiple Intelligence Teaching Tools (On-MITT) For Enhancing Interpersonal Teaching Activities. Proceedings of the 21st National Symposium on Mathematical Sciences, 786-791. Doi:10.1063/1.4887690.

Mohamad, S.N.M., Salleh, M.A.M. \& Salam, S. (2015). Factors Affecting Lecturers Motivation in Using Online Teaching Tools. Procedia-Social and Behavioral Sciences, $195,1778-1784$

Mohamad, S.N.M., Salam, S., \& Bakar, N. (2014). Lecturers' Perceptions and Attitudes towards the Usage of Online Learning at Polytechnic. International Journal of Science Commerce and Humanities. 2(1), 169-172.

Mohd, A. \&Abdullah, H. (2002). Guru sebagai Pendorong Dalam Darjah. Kuala Lumpur: PTS Publicators \& Distributing Sdn. Bhd.

Nunnally, J. C. (1978). Psychometric theory (2nd ed.). New York: McGraw-Hill.

Nunnally, J. C. and Bernstein, I. H. (1994). Psychometric theory (3rd ed.). New York: McGraw-Hill.

Rassiah K., Parahsakthi C. \& Haeryip S. (2011). The Higher Education Students 'Experiences with Technology. Asian Transactions on Basic \& Applied Sciences, $1(3), 1-9$.

Salam, S., Siti, N.M.M., Norasiken, B. \& Linda, K.M.S. (2014). The Designing of Online Multiple Intelligence Tools for Lecturers at Polytechnic. International Journal of Soft Computing and Software Engineering, 3(3), 1-7.

Thomson, R., Fitchen, C., Budd, J., Havel, A., \& Asuncion, J. (2015). Blending Universal Design, E-Learning, and information and communication technologies. In Se.E. Burgstahler (Ed., Universal design in higher education: From principles to practice (2nd ed.), 275-284. Boston: Harvard Education Press.

Woolfolk, A. (1990). Educational psychology (4th ed.). Englewood Cliffs, NJ: Prentice-Hall, 622

Yusof, C.M., \& Mariani, M.N. (2001). Personaliti pelajar pintar cerdas dan hubungannya dengan pencapaian akademik. Prosiding Konferensi Kebangsaan Kajian Pasca Siswazah. Serdang. Malaysia: Universiti Putra Malaysia.

Zakaria, M. H., Jason, W. \& Sylvia L. E. (2010). Investigating the Use Of Web 2.0 Technology By Malaysian Students, Multicultural Education \& Technology Journal, 4(1), $17-29$

Zikmund, W.G. and Babin, B.J. (2010). Essentials of Marketing Research (4th edition). Australia: South-Western.

Zimmerman, B. J. (2001). Theories of Self-Regulated Learning and Academic Achievement: An Overview and Analysis. Self-Regulated Learning and Academic Achievement. Theoretical Perspectives. B. J. Zimmerman and D. H. Schunk. Mahwah, N.J., Erlbaum, 1-38. 